\title{
JEJARING SOSIAL DALAM PEMBENTUKAN TIM SUKSES MANDIRI DI PEMILU DPRD KABUPATEN 2019
}

\author{
George Towar Ikbal Tawakkal, Ratnaningsih Damayanti, Tia Subekti, \\ Andrew D Garner, dan Thomas R. Seitz \\ Universitas Brawijaya, Malang \\ E-mail: george.ikbal@ub.ac.id
}

\begin{abstract}
ABSTRAK.
Perubahan dalam sistem pemilihan dan masalah partai politik dalam memobilisasi pemilih telah mendorong para kandidat untuk membangun tim sukses yang independen. Mereka adalah faktor penting dalam upaya memenangkan pemilu. Studi terbaru menunjukkan tentang keberadaan, kinerja, dan efisiensi merekadalam memberikan suara dalam pemilihan umum Indonesia dan banyak negara. Namun, sangat sedikit dari kajiankajian itu yang membahas tentang bagaimana tim sukses independen dibangun. Artikel ini menganalisis bagaimana para kandidat pemilihan legislatif di daerah mengembangkan tim sukses independen mereka. Berdasarkan wawancara dan pengamatan dari berbagai kandidat dalam pemilihan legislatif 2019 di Kabupaten Pati dan Kabupaten Demak, artikel ini membahas bagaimana para kandidat membangun tim sukses independen, yang mencakup bentuk dan sumber. Hasil studi ini menyatakan bahwa mereka memiliki aktor penting yang berhubungan dengan kandidat. Mereka terhubung secara sosial sebelum pemilihan, sehingga tim dibangun oleh transformasi fungsi sosial. Ini menunjukkan bahwa tim sukses independen mencerminkan jejaring sosial kandidat.
\end{abstract}

Kata kunci: Tim sukses mandiri; pemilu; jejaring sosial

\begin{abstract}
.
Changes in the electoral system and problems of political parties in mobilizing voters have led candidates to build independent success teams. They were an essential factor in winning effort. Recent studies showed their existence, performance, and efficiency in delivering votes in Indonesian elections and many countries. However, very few of them addressed about how the teams were built. This article analyzed how candidates of regional legislative elections develop their independent success teams. Based on interviews and observations of various candidates in the 2019 legislative election of Pati Regency and Demak Regency, this article discusses how candidates built an independent success team, which includes the form and sources. The results state that they have crucial actors who relate to candidates. They were connected socially before the election, so the team was built by social function transformation. It shows that the independent success team reflects the candidate's social network.
\end{abstract}

Key words: independent success team; election; social network

\section{PENDAHULUAN}

Pemanfaatan tim pemenangan di luar partai politik pengusungnya lazim dijumpai di pemilu Indonesia, baik pemilu eksekutif maupun pemilu legislatif (lihat Aspinall, 2014; Aspinall dan Sukmajati, 2015; Triantini, 2015; Noor Rahman, 2015). Tim pemenangan diartikan sebagai tim yang membantu kandidat untuk memenangkan pemilu, dengan mencarikan suara pemilih untuk kandidat. Masyarakat Indonesia lebih umum menyebutnya tim sukses, yang secara bahasa memiliki arti sekelompok orang yang bertugas untuk memperjuangkan calon yang diusungnya (Capres, Cagub, Cabup/ Cawakot) agar berhasil meraih kemenangan dalam suatu pemilihan. Tim sukses ini ada yang dibentuk oleh partai, ada juga yang ditentukan sendiri oleh sang calon (Kamuslengkap.com). Karena sifatnya yang berada di luar institusi partai, maka tim sukses yang dibentuk secara mandiri oleh kandidat dapat disebut tim sukses mandiri.

Bukan hanya di Indonesia, pemanfaatan lembaga semacam itujuga menjadi fenomena yang lazim dijumpai di berbagai negara. Keberadaannya menjadi fakta adanya variasivariasi yang muncul dalam praktik demokrasi di berbagai negara. Sebagai contoh dinegaranegara Amerika selatan, diVenezuela (Frey dkk, 2019), Meksiko (Larreguy dkk, 2016), Brazil (Gingerich dan Medina, 2013), Argentina (Zarazaga, 2014), dan Paraguay (Finan dan Schechter, 2012). Di Negara-negara Asia, seperti di Taiwan (Mattlin, 2004; Wu dan Huang, 2004), 
Thailand (Hellmann, 2014). Bahkan di negaranegara yang dianggap non-demokratis seperti di China (Kennedy, 2010), dan di Mesir era rezim otoriter (Blaydes, 2006).Bahkan pemanfaatan tim pemenangan di luar partai politik juga dilakukan di negara maju, seperti di Rusia (Frey dkk, 2019).

Dalam literatur kepemiluan, seperti artikelartikel yang ditulis oleh Frey dkk (2019), Larreguy dkk (2016), Gingerich dan Medina, (2013), Zarazaga (2014), dan berbagai artikel lainnya, lembaga semacam itu sering dianggap sebagai makelar suara, atau setidaknya salah satu unsurnya adalah makelar suara. Penyematan atribut makelar suara kepada aktor tim sukses mandiri yang terlibat pada politik uang, pada dasarnya dapat mempersempit pemahaman hanya pada konteks saluran distribusi uang/ barang, sebagaimana dilakukan oleh mayoritas peneliti di atas dalam artikel-artikel mereka. Meskipun kata "makelar", tidak selalu merujuk pada politik uang. Setidaknya ada peneliti yang memilih menerapkannya. Baldwin (2016) menggunakan kata "makelar suara" juga untuk merujuk pada aktor yang mengarahkan suara pemilih dengan paksaan, kewibawaan, ataupun timbal-balik.

Kesimpangsiuran penyematan "makelar suara" untuk tim pemenangan di luar partai politik juga terjadi, seperti tergambar dalam buku Callahan (2018) ketika menjelaskan kesimpangsiuran para peneliti menyebut tim pemenangan yang oleh masyarakat lokal di Thailand disebut Huakhanaen. Para peneliti menyebutnya dengan istilah yang berbeda-beda, seperticanvasser (peminta suara), atau vote gatherer (pengumpul suara), atau vote broker (makelar suara), atau pun vote bank (bank suara).

Namun, sebagai konsekuensi literatur yang didominasi dengan penyematan "makelar suara" pada tim pemenangan di luar lembaga partai politik, khususnya para peneliti yang mengkaji di Indonesia, artikel ini akan berangkat dari kajiankajian yang ada,termasuk kajian pemakelaran suara yang cenderung membahasnya dalam konteks politik uang.

Kajian-kajian tentang lembaga semacam itu, sebagaimana disampaikan para peneliti di atas, sebenarnya secara tidak langsung telah memberikan pemahaman bahwa keberadaannya bersifat sebagai perantara, yang menjembatani antara kandidat dan pemilih. Seperti Finan dan
Schechter (2012), menggambarkannya dengan kalimat "...to interact with voters...", yang menunjukkan perannya sebagai aktor yang menggantikan kandidat untuk bersentuhan langsung dengan pemilih. Beberapa peneliti lain, seperti Aspinall (2014) lebih tegas menyebutnya sebagai saluran distribusi materi kepada pemilih.

Sementara peneliti lain mendefinisikannya secara lebih umum, yakni sebagai orang-orang yang menjembatani antara kandidat dan pemilih, dalam rangka mengumpulkan suara bagi kandidat (Hellmann, 2014; Ocantos dkk, 2012; Blaydes, 2006). Mengingat posisinya sebagai orang yang menjadi penengah, aktor-aktor di dalam lembaga tersebut kadang juga disebut sebagai middleman (Scott, 1972; Finan dan Schecther 2012).

Mengenai kenapa kandidat memanfaatkan tim sukses mandiri, beberapa kajian memberikan penjelasan yang berbeda. Seperti Blaydes(2006), menjelaskan kemunculannya sebagai akibat dari kecenderungan lemahnya partisipasi pemilih. Rezim otoriter di Mesir dilihat sebagai penyebab keengganan pemilih untuk menggunakan hak suaranya, karena pemerintah dianggap tidak mampu memenuhi kebutuhan publik, dan itu mengecewakan pemilih. Partai pemerintah pun dianggap sebagai bagian dari rezim otoriter, yang tentu tidak popular di mata pemilih. Kemudian, kandidat memanfaatkan jaringan sosial yang ada di tingkat bawah untuk bekerja sebagai tim pemenangan.

Pada sisi pemilih, selain ketidakpercayaan para pemilih terhadap rezim otoriter sebagaimana dijelaskan Blaydes, terdapat penjelasan yang lebih transaksional disampaikan oleh Hellmann. Hellmann (2014), menyebut adanya keinginan pemilih untuk memperjualbelikan suara, sehingga dibutuhkan perantara untuk mengkomunikasikan jual beli tersebut.

Aspinall (2014) memberikan penjelasan yang berbeda. Perubahan tren kampanye, dari berpusat di partai menjadi berpusat di kandidat, mendorong kandidat untuk membangun mesin mobilisasi suara secara mandiri, yang bertumpu pada jejaring sosial. Jejaring sosial didefinisikan sebagai jejaring individual yang bersumber dari interaksi dalam kehidupan sehari-hari (McCarty dkk, 1997). Jejaring ini dapat berupa keluarga, teman, mitra kerja, dan lain sebagainya. Dalam artikel ini, jejaring model demikian disebut sebagai jejaring sosial asli, yakni jejaring sosial 
yang ada dalam kehidupan sehari-hari individu, di luar konteks kepemiluan.

Lebih lanjut, kajian Tawakkal (2009) menunjukkan tidak berfungsinya partai politik sebagai sebuah lembaga mobilisasi pemilih. Secara lebih detail, Tawakkal(2017)menjelaskan keberadaan tim sukses mandiri bukan hanya kebutuhan kandidat, namun juga kebutuhan pemilih. Kandidat maupun pemilih, secara bersamaan membutuhkan kehadiran perantara. Meskipun para peneliti memberikan latar belakang yang berbeda mengenai keberadaan tim sukses mandiri, namun ada kesamaan yang dapat dipahami bahwa keberadaanya disebabkan oleh ketidakmampuan untuk terjadinya hubungan langsung antara kandidat dan pemilih. Ketidakmampuan itu entah disebabkan oleh ketidakmampuan kandidat, maupun oleh pemilih, dalam hal ini menjadi tidak penting, karena kenyataannya terdapat ketidakterhubungan antara mereka.

Kajian-kajian tentang tim sukses mandiri, setidaknya dapat dibagi ke dalam dua ranah besar, yakni bagaimana tim tersebut bekerja, dan bagaimana pelembagaan tim tersebut. Ranah pertama adalah paling banyak dikaji oleh para peneliti, sedangkan yang kedua masih sangat sedikit. Ranah pertama mencakup motivasi, fungsi, prosedur kerja, hingga perilaku para aktor di dalamnya. Diantara kajian yang masuk ranah pertama adalah kajian Hellmann dan Aspinall. Hellmann (2014), menjelaskan keterlibatan para aktor dimotivasi oleh keinginan mendapatkan perlindungan bisnis, perlindungan hukum, atau pekerjaan (Hellmann, 2014).

Artikel Aspinall (2014) menjelaskan secara lebih variatif mengenai perilaku tim sukses. Aspinall mengklasifikasikan aktor-aktor di tim sukses mandiri (yang disebutnya broker atau makelar) ke dalam tiga bentuk, yakni activistbroker, clientelist broker, dan opportunist broker. Activist broker merujuk pada orang yang mendukung kandidat berdasarkan komit-men politik, etnis, agama, dan sejenisnya. Clientelist broker merujuk pada orang yang sudah memiliki hubungan lama dengan kandidat, dengan motivasi menerima keuntungan di kemudian hari. Opportunist brokermerujuk pada orang yang hanya mencari keuntungan jangka pendek.

Kajian lain yang juga masuk ranah pertama adalah kajian Tawakkal (2017) yang menjelaskan gengsi sosial sebagai salah satu motivasi keterlibatan para aktor di tim sukses mandiri. Kelompok sosial tertentu merasa perlu untuk terlibat pemenangan kandidat sebagai ajang pertunjukan sumber daya yang dimiliki oleh kelompok tersebut. Keterlibatan seseorang menjadi tim sukses, bukan hanya didasari semangat kepemiluan, namun lebih didasari semangat sosial.

Masih di ranah pertama, beberapa peneliti fokus pada cara kerja dan fungsi tim tersebut. Seperti kajian Frey dkk (2019) yang fokus pada bagaimana tim berfungsi mengintimidasi pemilih. Terdapat pula kajian Rueda (2016), yang membahas kinerja makelar suara dengan mencari korelasi antara cakupan tempat pemungutan suara dan ukuran jual beli suara. Begitu pula Finan dan Schecther (2012), yang mengkaji keberhasilan kinerja tim. Aktor-aktor dalam tim dapat membantu kandidat untuk melakukan pemetaan politik, yang bermanfaat dalam praktik jual beli suara. Mereka memiliki kontak langsung dan lebihmemahamikonstituen. Ini berfungsi untuk memprediksi kecenderungan pemilih dan tingkat perasaan balas budi pemilih.

Hellmann (2014) menyebutkan, di Jepang, para kandidat memanfaatkan mesin klientelisme yang disebut koenkai, yakni dengan mensponsori beberapa kegiatan yang dapat memperkenalkan si kandidat.Koenkai juga menjadi pihak yang menyerahkan materi kepada pemilih. Bahkan para peneliti secara khusus memposisikannya sebagai lembaga yang menopang politik uang. Di beberapa negara, seperti di Taiwan dan Thailand, keberadaan tim tersebut dalam rangka mengkontrol praktik jual beli suara. Kajiankajian yang dilakukan oleh Aspinall (2014), Aspinall dan Sukmajati (2015), Triantini (2015), Noor Rahman (2015), menempatkannya dalam kerangka berpikir klientelisme (politik uang). Seperti Aspinall (2014) yang menjelaskan praktik klientelisme dalam politik elektoral. Sementara itu, Triantini (2015) mempertegas tentang arti penting makelar suara dalam menyediakan jaringan politik uang, bahkan menentukan keberhasilan politik uang.

Ranah kedua, ranah organisasi tim sukses mandiri, tidak banyak ditemukan dalam literatur. Beberapa literatur yang menyiratkan bentuk organisasi tim sukses mandiri pun masih dangkal dalam mengupas pengorganisasian tim tersebut. Seperti Finan dan Schecther (2012), yang menyebutkan latar belakang para aktor, 
yakni para community leader atau middleman di pedesaan-pedesaan. Olli Hellmann (2014) menjelaskan bahwa di Taiwan, partai menjalin hubungan dengan para vote broker (tiau-a-ka), yang direkrut dari para politikus lokal, pemimpin geng kriminal, kepala organisasi relawan, atau pengusaha. Begitu pula di Thailand, Hellmann, yang biasanya adalah para individu yang memiliki pengaruh signifikan di komunitasnya, semisal kepala desa, guru, pengusaha. Di Thailand juga terdapat gang kriminal Chao Pho yang menyediakan jaringan jual beli suara yang lebih efektif.

Keterbatasan literatur di ranah kedua, membawa konsekuensi pada penjelasan yang kurang komprehensif ketika berbicara mengenai ranah pertama. Seperti dalam konteks Thailand, bagaimana kinerja tim sukses mandiri yang berlatarbelakang geng kriminal? Dalam konteks Indonesia, merujuk pada kajian Aspinall (2014), bagaimana proses rekruitmen tim sukses yang pada ujungnya menghasilkan tiga karakteristik broker? Atau, merujuk pada kajian Finan dan Schechter (2012), apakah latar belakang keterlibatan para tokoh masyarakat menjadi pertimbangan pemilih dalam membangun perasaan balas budi?

Artinya, masih sangat minim penjelasan mengenai pola pembentukan dan bentuk tim sukses mandiri, yang pada dasarnya dapat menjadi salah satu sisi dalam memahami perilaku tim sukses mandiri. Artikel ini mengisi keterbatasan literatur, dengan mengkaji lebih dalam mengenai pembentukantim sukses mandiri. Dengan memahami pembentukan tim sukses mandiri, diharapkan dapat menjadi pintu untuk lebih memahami kinerja tim sukses secara komprehensif dan mendorong para peneliti untuk memperluas kajian tim sukses mandiri di luar konteks politik uang ataupun pemakelaran suara.

\section{METODE}

Dalam rangka menjelaskanpembentukan tim sukses mandiri, artikel ini didasarkan pada penelitian kualitatif, dengan metode pengumpulan informasi melalui wawancara mendalam terhadap 30 orang yang berlatar belakang tim sukses mandiri, calon anggota DPRD kabupaten, pimpinan partai politik, dan penyelenggara pemilu, dalam kurun waktu pelaksanaan Pemilu DPRD 2019 di Kabupaten Pati dan Kabupaten Demak.Metode kualitatif sangat diperlukan karena kebutuhan informasi yang mendalam mengenai jejaring sosial yang ada di antara para aktor, serta kebutuhan terhadap respon cepat untuk berkembang berdasar informasi yang didapat.

Merujuk pada berbagai literatur yang mengkaji tim sukses mandiri, seperti Aspinall (2014), Zarazaga, 2014),dan Finan dan Schechter (2012, diketahui bahwa tim sukses mandiri ditopang oleh jejaring sosial. Sehingga pola jejaring sosial di masyarakat menentukan komponen tim sukses mandiri. Pemilihan dua Kabupaten tersebut karena dapat mewakili dua tipologi masyarakat Jawa yang disampaikan oleh Geertz (1989), yakni santri dan abangan. Masyarakat Demak layak dikategorikan sebagai masyarakat santri, dan masyarakat Pati layak dikategorikan sebagai masyarakat abangan.

Obyek kajian artikel iniadalahpembentukan tim sukses mandiri. Sedangkan subjeknya adalah individu-individu di dalam tim sukses dan kandidat. Pemilihan informan berlatarbelakang pimpinan partai politik disebabkan posisi penting mereka dalam mengawasi kampanye para calon. Peneliti juga merasa perlu mewawancarai penyelenggara pemilu, karena kemampuan mereka menyediakan informasi tentang pihakpihak yang terlibat dalam pemenangan kandidat.

Pertanyaan-pertanyaan yang diajukan berkisar pada keberadaan tim sukses mandiri, struktur, dan hubungan-hubungan sosial antar individu. Selain melakukan validasi informasi melalui wawancara mendalam antar informan, peneliti juga melakukan pengamatan langsung terhadap kegiatan tim sukses mandiri, seperti rapat-rapat dan interaksi antar individu. Informasi-informasi tersebut kemudian dianalis melalui proses reduksi data, penyajian data, penarikan kesimpulan/verifikasi (Miles \& Huberman, 1992).

Artikel akan terbagi dalam beberapa pembahasan. Pertama, eksistensi tim sukses mandiri di masyarakat. Pembahasan ini diperlukan di awal, untuk memperjelas posisi dan penyebutan para aktor. Mengingat ada banyak jenis aktor yang terlibat di kepemiluan, sehingga rawan terjadi salah paham bila tanpa penjelasan di awal. Kedua, struktur tim sukses mandiri yang dimiliki oleh calon anggota DPRD Kabupaten di Pemilu 2019, merujuk pada bentuk organisasi 
sebagai suatu tim. Arti penting pembahasan ini adalah untuk mengidentifikasi aktor-aktor simpul dalam tim.

Ketiga, hubungan-hubungan sosial yang dimiliki antara kandidat dan aktor simpul, serta proses pembentukannya. Peneliti memilih untuk melihat hubungan sosial antara kandidat dan aktor-aktor di tim sukses mandiri sebagai pintu masuk pembahasan pembentukan tim sukses mandiri.Hal ini merujuk pada kajian-kajian di atas yang dapat disimpulkan adanya latar belakang tertentu yang menyebabkan seseorang terlibat dalam tim. Seperti kajian Aspinall (2014) tentang adanya clientilist broker, yang mengindikasikan adanya hubungan sosial antara kandidat dan broker sebelum kegiatan kepemiluan.

Keempat, pembentukan argumen dengan mendiskusikan data-data dan literatur-literatur yang sudah ada. Pada bagian ini akan terjawab bagaimana pola pembentukan tim sukses mandiri oleh kandidat, serta gambaran besar apa yang dapat dipahami.Artikel ini diakhiri dengan penyimpulan argumentasi mengenai pembentukan tim sukses mandiri.

\section{HASIL DAN PEMBAHASAN}

\section{Tim sukses dalam konteks lokal}

Di masyarakat Kabupaten Demak dan Kabupaten Pati, istilah tim sukses baru dipergunakan dalam kurun waktu dua puluhan tahun terakhir. Secara historis, masyarakat memiliki istilah lokal untuk menyebut organisasi atau aktor yang berfungsi membantu kandidat memenangkan pemilu, sepertipecut,gapit (Tawakkal, 2017) dan sabet (Aspinall dkk, 2017). Masyarakat di Kabupaten Demak, khususnya di kecamatan Mranggen menggunakan kata gapit untuk menyebut orang-orang yang membantu kandidat memenangkan pemilu (Tawakkal, 2017), sedangkan masyarakat di Kabupaten Pati menyebutnya sabet.

Secara bahasa, gapit memiliki arti sesuatu yang digunakan untuk menjepit (Tawakkal, 2017). Dalam konteks pemilu, gapit adalah orang-orang yang "menjepit" pemilih agar mantap memberikan suaranya pada kandidat tertentu. Dalam bahasa Jawa, Sabet merujuk pada alat serupa tali (bukan benda keras) yang digunakan untuk memukul. Pecut lebih spesifik, alat serupa tali yang digunakan untuk memukul sesuatu dalam rangka membuat sesuatu tersebut bergerak. Dalam konteks pemilu, Pecut atau Sabet adalah orang-orang yang "menyabet" pemilih agar bergerak ke TPS dan memilih kandidat tertentu.

Sejalan dengan penjelasan Tawakkal (2017), istilah lokal tersebut digunakan untuk merujuk pada orang-orang yang membantu kemenangan seseorang dalam pemilu, pertama kali muncul di pemilihan kepala desa (Pilkades). Tidak diketahui secara pasti kapan pertama kali istilah tersebut muncul. Namun hampir seluruh informan menyatakan bahwa istilah tersebut pertama kali merujuk pada tim pemenangan di Pilkades. Merujuk pada penjelasan Nurcholis (2011), masyarakat Indonesia telah mengenal pemilihan jabatan politik sejak era kolonial Inggris, sekitar tahun 1811-1816. Pemerintahan kolonial di bawah Raffles telah mengubah mekanisme pengisian jabatan kepala desa, dari yang sebelumnya melalui mekanisme turun temurun berdasar keturunan, menjadi pemilihan langsung.

Fakta temuan bahwa penggunaan istilah lokal untuk menyebut tim pemenangan telah dipakai sejak lama di Pilkades, serta keberadaan literatur yang menyebutkan bahwa Pilkades telah dipraktekkan dalam kurun waktu sekitar dua ratus tahunan, maka dapat dipahami bahwa penggunaan keberadaantim pemenangan dengan penyebutan istilah lokal telah hadir dan menjadi bagian dari budaya politik di masyarakat.

Perubahan iklim demokrasi di akhir abad keduapuluh, serta perubahan sistem pemilu di awal abad 21, memperlebar locus pemanfaatan tim pemenangan. Perubahan mekanisme penentuan kepala daerah, dari dipilih oleh anggota DPRD menjadi dipilih langsung oleh rakyat, menjadi pemicu bergesernya fokus kampanye kandidat. Kampanye menjadi lebih terpusat pada kandidat, dan mendorong kandidat untuk membentuk jaringan kampanye yang meliputi para makelar suara (Aspinall, 2014). Pilkada menampilkan kontestasi politik yang hanya diikuti oleh beberapa kandidat.

Kandidat yang ditampilkan juga seringkali diajukan oleh gabungan beberapa partai. Hal ini menjadikan Pilkada sulit dilihat sebagai kontestasi antarpartai, tetapi lebih pada kontestasi antar kandidat. Dinamika tersebut mengingatkan pada Pilkades, di mana kandidat adalah peserta kontestasi politik.Kesamaan antara Pilkada 
dan Pilkades, yakni berpusat pada kandidat, menyebabkan diadopsinya dinamika Pilkades ke dalam dinamika Pilkada, termasuk dalam membangun tim pemenangan mandiri di luar lembaga partai politik.

Keberadaan tim pemenangan di luar partai politik, kemudian masuk dan dikenal di pemilu legislatif. Pada tahun 2008, terjadi perubahan regulasi Pemilu, dengan disahkannya UndangUndang No 10/2008 tentang Pemilu anggota DPR, DPD, dan DPRD. Namun, kemudian pasal 214 huruf a, b, c, d, dan e, yang berbicara mengenai penentuan kursi berdasar perolehan suara calon sebesar 30\%, dibatalkan oleh Mahkamah Konstitusi (MK).

Dengan pembatalan tersebut, maka sistim pemilu 2009 berubah menjadi sistem proporsional terbuka. Pemilih diberikan pilihan yang sama besarnya antara memilih partai atau calon anggota legislatif (caleg). Caleg dengan suara yang lebih banyak maka lebih berhak menempati kursi yang didapat oleh partainya. Bukan lagi berdasar pada perolehan Bilangan Pembagi Pemilih (BPP). Pertarungan caleg antarpartai maupun sesama partai menjadi lebih marak. Caleg menjadi aktor yang mendominasi proses pemilu. Partai, sebagai sebuah lembaga, gagal mengambil peran dalam mendulang suara pemilih (Tawakkal, 2009). Sehingga, pemilu 2009 mendorong kandidat untuk membentuk tim pemenangan sendiri, di luar partai politiknya.

Bagi masyarakat desa, situasi tersebut mirip dengan Pilkades, di mana terdapat kandidat yang berusaha memenangkan suara pemilih. Pada tataran ini, sebagaimana juga terjadi pada Pilkada, dinamika yang ada pada Pilkades "diadopsi” oleh pemilu legislatif. Kehadiran tim pemenangan di luar partai politik,dengan mudah diterima sebagai bagian dari kontestasi pemilu legislatif. Secara umum, tim pemenangan di luar partai politik hadir dan dikenal pada pemilu legislatif dimulai sejak pemilu 2009 dan berkembang lebih marak pada pemilu-pemilu berikutnya, hingga pemilu terbaru 2019.

Seiring berjalannya waktu, terjadi perubahan penyebutan untuk tim pemenangan. Masyarakat dewasaini lebihumum mengenalnya dengan sebutan tim sukses, meskipun masih ada juga yang mempertahankan penggunaan istilah lokal. Secara bahasa, tim sukses bermakna tim yang berfungsi mensukseskan kandidat. Istilah tim sukses pada dasarnya memiliki cakupan yang luas, meliputi tim pemenangan yang berlatar belakang partai politik, maupun yang di luar partai politik. Bahkan beberapa peneliti mengidentifikasi lebih rinci, dengan menempatkan makelar suara sebagai salah satu unsur dalam tim sukses.

Terlepas dari perdebatan yang dapat muncul terkait pengidentifikasian unsur-unsur yang ada di tim sukses, artikel ini hanya akan fokus pada unsur-unsur tim sukses yang berada di luarlembaga partai politik. Artikel ini menyebutnya sebagai tim sukses mandiri, yakni tim pemenangan yang dibentuk secara mandiri oleh kandidat, untuk secara khusus membantu memenangkan pemilu, meskipun di banyak literatur membahasnya sebagai makelar suara dalam konteks politik uang.

\section{Struktur tim sukses mandiri}

Hasil wawancaradi Kabupaten Pati dan Kabupaten Demak menunjukkan bahwa tim sukses mandirimemiliki beberapa bentuk. Beberapa orang menyatakan dirinyaadalah tim desa. Mereka ini direkrut langsung oleh calon anggota DPRD Kabupaten yang memiliki daerah pemilihan di desa yang ditempati oleh orangorang tersebut. Bahkan mereka juga memberi kesaksian adanya koordinator di hampir seluruh desa, kecuali kandidat yang memilih wilayah kerja tertentu, tidak seluruh desa di daerah pemilihan.

Pemilihan wilayah desa sebagai unit tim sukses mandiri dikarenakan dua hal, keterbatasan sumber daya finansial kandidat, atau strategi kampanye dengan mempertimbangkan peluangpeluang suara di desa tertentu. Kesaksian ini diperkuat dengan hasil wawancara terhadap kandidat, yang menyatakan keberadaan koordinator desa dan pemilihan desa tertentu. Desa dipilih sebagai salah satu tingkat koordinasi tim sukses mandiri karena faktor administrasi kewilayahan dan kondisi masyarakat yang mungkin terpisah antara satu desa dan desa lain secara geografis ataupun karakteristik.

Mereka juga menyatakan adanya individuindividu yang memiliki wilayah kerja di bawah desa. Beberapa informan menyebutkan adanya tim sukses di tingkat Rukun Warga (RW). Pada tingkatan ini, lazimnya terdiri dari dua orang atau lebih di masing-masing RW. Sama dengan tingkat desa, tidak semua RW terdapat tim sukses. Namun sedikit berbeda dengan 
tingkat Desa yang memiliki alasan sumberdaya dan potensi suara, keputusan tentang ada atau tidaknya tim sukses RW lebih dikarenakan keterbatasan sumber daya manusia yang dapat direkrut menjadi tim sukses, serta potensi suara pemilihnya.

Sebagai contoh, terdapat kandidat yang berasal atau berdomisili di RW tertentu, maka kandidat lain memilih untuk tidak berkampanye di RW tersebut dengan alasan kecilnya peluang meraih suara, dan sulitnya menemukan warga RW tersebut yang bersedia menjadi tim sukses karena telah "terikat" dengan kandidat yang berasal dari RW tersebut. Atau pada kasus tertentu diketahui bahwa jumlah pemilih di RW tersebut didominasi oleh keluarga besar kandidat lain, sehingga merasa akan sia-sia bila membentuk tim yang bertujuan mempengaruhi warga RW tersebut.

Di bawah tingkat RW, terdapat tim yang bekerja di tingkat Rukun Tetangga (RT). Tingkat inilah yang bersentuhan langsung dengan pemilih, baik dalam konteks politik uang maupun penyampaian program kandidat. Bahkan gesekan antar tim sukses sering terjadi di tingkat ini, yang disebabkan oleh kedekatan jarak sosial antar aktor di satu tim dengan tim lainnya untuk kandidat yang berbeda. Lazimnya, pada tingkat RT hanya terdapat satu orang di tim sukses.

Berbeda dengan tim sukses di tingkat desa maupun RW, keberadaan tim sukses tingkat RT cenderung merata di satu RW. Artinya, ketika kandidat memilih suatu desa dan memilih RW tertentu untuk dibentuk tim sukses mandiri, kandidat membentuk tim sukses mandiri di seluruh RT di wilayah tersebut. Wawancara kepada kandidat menjawab alasan kenapa tidak dilakukan pemilihan wilayah tertentu untuk tingkat RT, yakni karena menghindari kecemburuan pemilih antar RT ketika pembagian uang. Kecemburuan ini dikhawatirkan dapat memicu pandangan negatif terhadap kandidat oleh warga RT yang tidak menerima uang.

Beberapa informan menjelaskan bentuk tim sukses mandiri yang berbeda dengan di atas. Tim sukses mandiri yang hanya terdiri dari satu orang, yang tidak memiliki turunan tingkat di bawahnya. Umumnya, orang tersebut memiliki wilayah kerjasatu desa. Secara tingkatan dan jumlah orang, sejajar dengan tim sukses tingkat desa (lihat bagan 1). Bahkan, di beberapa desa dijumpai adanya dua tim sukses yang secara struktur terpisah, namun bekerja untuk satu kandidatyang sama. Tim sukses jenis ini memang tidak diarahkan sebagai saluran politik uang, namun lebih diarahkan sebagai influencer. Aktoraktor dalam tim sukses jenis ini dimanfaatkan sebagai "penjamin" atas kelayakan kandidat untuk dipilih. Status dan reputasi sosial yang melekat pada aktor-aktor tersebut dimanfaatkan dalam rangka mempengaruhi pemilih.

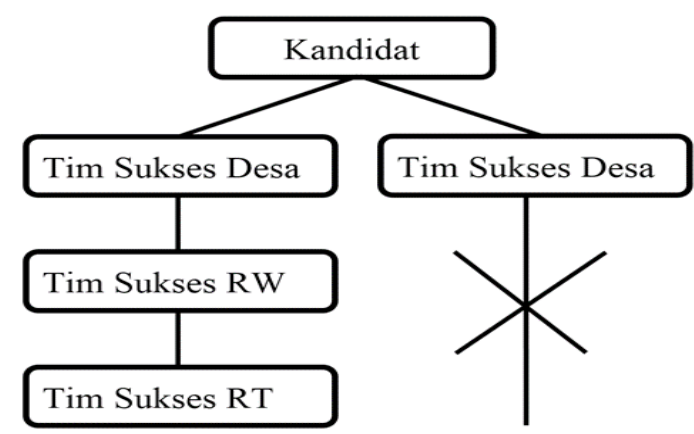

Gambar 1. Struktur Tim Sukses Mandiri

Keberadaan aktor-aktor tim sukses mandiri di berbagai tingkatan tersebut, faktanya tidak direkrut ataupun dibentuk langsung oleh kandidat. Beberapa informan yang berposisi sebagai tim sukses tingkat RT menyatakan bahwa mereka direkrut oleh tim sukses tingkat RW. Meskipun ada juga yang direkrut oleh tim sukses tingkat desa, namun jumlahnya tidak dominan. Begitu pula tim sukses tingkat RW, mereka direkrut oleh tim sukses tingkat desa. Peneliti tidak menemukan tim sukses tingkat RW yang direkrut langsung oleh kandidat. Kandidat hanya merekrut langsung aktor-aktor tim sukses tingkat desa (lihat Gambar 2).

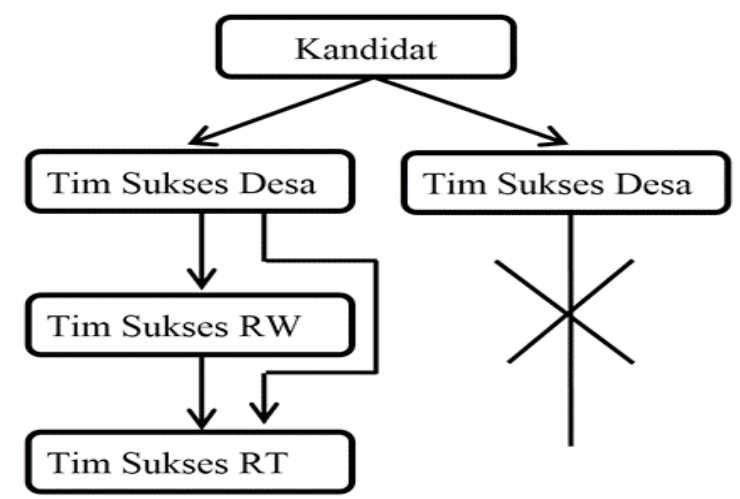

\section{Gambar 2. Alur Rekruitmen}

Salah seorang kandidat memberikan alasan kenapa kandidat hanya merekrut secara langsung tim sukses tingkat desa, karena jumlah desa lah yang menyebabkan paling memungkinkannya 
tim sukses dikelola langsung oleh kandidat. Sebagai gambaran, satu daerah pemilihan untuk Pemilu DPRD Kabupaten, dapat terdiri dari beberapa kecamatan. Satu kecamatan dapat terdiri dari 20 puluhan desa. Sedangkan bila mengelola secara langsung tim sukses tingkat RW, jumlahnya dapat mencapai lebih dari 70 tim. Hal tersebut dinilai di luar kemampuan kandidat.

Pertanyaannya kemudian, kenapa kandidat tidak membentuk tim sukses kecamatan? Peneliti hanya menjumpai sedikit sekali kandidat yang memiliki tim sukses aktif di tingkat kecamatan. Keberadaan tim sukses kecamatan dianggap tidak diperlukan, mengingat satu daerah pemilihan hanya terdiri dari satu hingga empat kecamatan. Di samping alasan kuantitas, juga terdapat alasan kualitas, bahwa seringkali tidak ditemukan orang-orang yang memiliki jaringan sosial di banyak desa dalam satu kecamatan. Sehingga kandidat memilih untuk mengoptimalkan interaksi dengan tim sukses tingkat desa.

Pola koordinasi yang dilakukan oleh tim sukses berjenjang sesuai dengan tingkatan. Ketika kandidat memberikan arahan kerja ataupun materi untuk didistribusikan, maka akan disampaikan secara langsung kepada tim sukses desa. Lazimnya, arahan-arahan dan materi disampaikan oleh kandidat dengan mengadakan forum-forum pertemuan antara kandidat dan tim sukses tingkat desa. Meskipun terkadang terdapat kehadiran tim sukses tingkat RW, namun sifatnya hanya "figuran" dalam konteks forum rapat koordinasi.

Kandidat juga memanfaatkan saluran pribadi untuk memberikan arahan atau materi kepada tim sukses desa, khususnya bila arahan atau materi tersebut mendesak dan/atau berbeda dengan tim sukses desa lainnya. Sebagai catatan, kandidat juga terkadang mengadakan forum yang menghadirkan seluruh tim sukses di segala tingkatan, namun lebih bersifat "pesta" daripada koordinasi. Setelah tim sukses tingkat desa menerima arahan atau materi dari kandidat, mereka meneruskannya ke tim sukses tingkat RW, hingga tim sukses tingkat RT secara estafet. Begitu juga sebaliknya, alur pelaporannya dari tim sukses tingkat RT secara estafet hingga ke kandidat.

Dari penjelasan bagian ini dapat dipetakan bahwa terdapat dua bentuk tim sukses mandiri calon anggota DPRD Kabupaten, yakni bertingkat dan tunggal. Tim sukses mandiri bertingkat merujuk pada unit tim sukses yang berjenjang dari tingkat desa hingga tingkat RT, dengan pola koordinasi dan pelaporan secara estafet sesuai tingkatan (lihat Gambar 3). Tim sukses bertingkat terdiri dari tim sukses desa, tim sukses RW, dan tim sukses RT. Struktur ini mirip tim sukses di Pilkades (lihat Tawakkal, 2017).

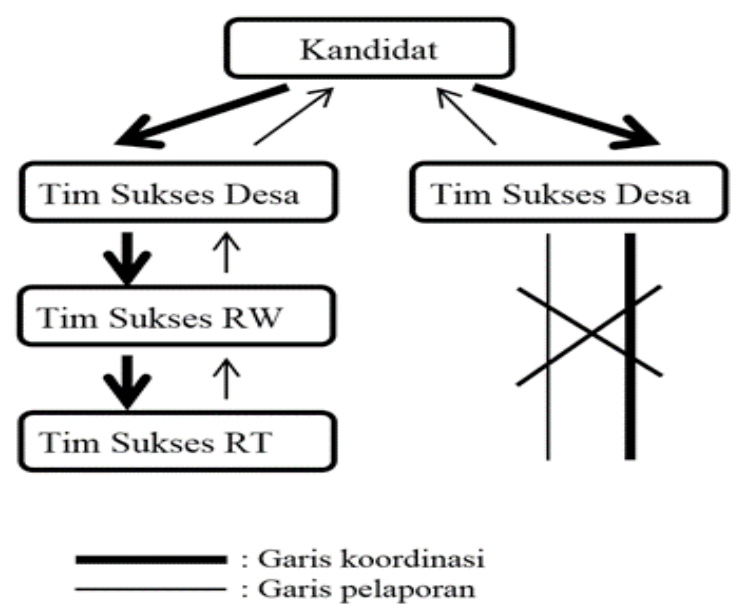

Gambar 3. Alur Koordinasi dan Pelaporan

Tim sukses RT adalah tim sukses yang memiliki wilayah kerja di lingkup Rukun Tetangga, dan berfungsi untuk berinteraksi langsung dengan pemilih. Besaran Rukun Tetangga dapat mencapai 30 keluarga, dimana masing-masing keluarga dapat terdiri dari beberapa orang yang memiliki hak pilih. Tim sukses RW adalah tim sukses yang memiliki wilayah kerja di lingkup Rukun Warga, dan berfungsi untuk mengkoordinasi tim sukses RT. Dalam satu Rukun Warga, setidaknya terdiri dari tiga Rukun Tetangga. Dalam konteks koordinasi, tim sukses RW setidaknya mengkoordinasi tiga unit kecil tim sukses RT.

Tim sukses mandiri tunggal merujuk pada unit tim sukses yang hanya berisi satu orang, yang secara otomatis memiliki pola koordinasi dan pelaporan secara langsung dengan kandidat. Tim sukses mandiri jenis ini bekerja secara individu, tidak memiliki struktur di bawah maupun di atas nya. Tim sukses mandiri tunggal biasanya diisi oleh elit-elit sosial. Secara spesifik, biasanya diisi oleh orang-orang berlatar belakang pengusaha ataupun tokoh agama. Mereka mempengaruhi pemilih secara langsung, yakni para pemilih yang menjadi pengikut atau pun pekerja nya.

Kesimpulan yang muncul dalam pembahasan ini, aktor tim sukses tingkat desa adalah 
aktor yang berhubungan langsung dengan kandidat, baik dalam konteks koordinasi ataupun pintu masuk pembentukan tim sukses hingga tingkat RT. Hal ini sekaligus menunjukkan bahwa aktor tim sukses tingkat desa adalah aktor simpul yang menjadi kunci bekerjanya suatu unit tim sukses. Kesimpulan ini penting, sebagai poin awal pembahasan pembentukan tim sukses.

\section{Pembentukan tim sukses mandiri}

Aktor-aktor tim sukses tingkat desa merupakan aktor simpul yang dapat menjelaskan pola pebentukan tim sukses mandiri oleh kandidat. Dalam rangka memetakan pola pembentukan tersebut, diperlukan gambaran mengenai hubungan sosial yang sudah ada antara kandidat dan aktor simpul. Mengingat interaksi kandidat dan aktor simpul adalah titik awal pembentukan tim sukses secara utuh.

Beberapa calon anggota DPRD kabupaten menyatakan bahwa mereka memanfaatkan keluarga sebagai tim sukses. Sebagai informasi awal, mayoritas kandidat berdomisili di daerah pemilihannya.Karakteristikmasyarakatpedesaan, terdapat individu yang memiliki keluarga besar yang secara aktif masih terhubung dalam interaksi sosial keseharian. Dalam konteks masyarakat pedesaan, keluarga besar merujuk pada dua entitas kekeluargaan, yakni keturunan dan perkawinan.

Kekeluargaan berdasar keturunan diartikan sebagai keterhubungan nasab atau keturunan yang berada pada satu garis kakek, bahkan hingga satu garis kakek buyut. Jumlahnya bisa banyak, mengingat karakteristik orang di masa lalu memiliki banyak anak. Sebagai gambaran minimal, seorang kakek buyut dapat memiliki lima anak (kakek). Begitu pun kakek, dapat memiliki lima anak (bapak atau paman), hingga masing-masing bapak atau paman dapat memiliki lima anak (saudara atau sepupu). Jumlahnya bisa mencapai puluhan jika hingga anak cucu.

Selain kekeluargaan berdasar keturunan, kandidat juga memanfaatkan kekeluargaan berdasar perkawinan, yakni merujuk pada keterhubungan kekeluargaan sebagai konsekuensi adanya ikatan perkawinan. Kombinasi antara kekeluargaan keturunan dan perkawinan dapat menghasilkan jumlah yang sangat besar, mengingat keluarga ipar juga memiliki keluarga besar berdasar keturunan. Jumlah besar ini dapat tersebar di lebih dari satu desa.
Pemanfaatan keluarga besar sebagai tim sukses mandiri juga dibenarkan oleh para tim sukses. Mereka secara moral berkewajiban untuk membantu kemenangan anggota keluarganya yang menjadi kandidat. Kandidat biasanya memilih salah satu anggota keluarga besar nya yang paling berpengaruh untuk menjadi tim sukses tingkat desa. Lazimnya, orang yang paling dituakan dan paling memiliki sumber daya (materi maupun non materi) akan direkrut untuk menjadi aktor simpul.

Kandidat menjelaskan arti penting keluarga besar dalam tim sukses independen. Salah satu pertimbangan utama bagi kandidat ketika memutuskan menjadi peserta pemilu adalah ukuran keluarga besar. Hal ini dianggap sebagai sumber daya sosial yang potensial. Seorang kandidat yang memiliki keluarga besar dengan jumlah yang banyak, merasa percaya diri untuk memenangkan pemilu. Bahkan, sebagaimana kesaksian salah satu pimpinan partai, penjaringan kandidat juga mempertimbangkan ukuran keluarga besar yang dimiliki oleh seorang bakal kandidat.

Keterbatasan keluarga besar yang hanya ada pada dua atau tiga desa, mendorong kandidat untuk memanfaatkan saluran sosial lainnya, yakni pertemanan. Teman dalam konteks ini merujuk pada orang-orang yang sudah dikenal oleh kandidat, yang masih memiliki interaksi sosial meskipun dalam kadar yang rendah. Antara kandidat dan orang-orang tersebut tidak terikat secara ketat pada payung lembaga sosial tertentu, semisal pekerjaan. Pemanfaatan temanteman ini memiliki cakupan yang lebih luas dari pemanfaatan keluarga besar. Seorang kandidat dapat memiliki teman di banyak desa, bukan hanya satu atau dua desa.

Dari sisi periodisasi, terdapat dua jenis pertemanan yang dimanfaatkan oleh kandidat, yakni teman saat ini dan teman lama. Teman saat ini merujuk pada pertemanan antara kandidat dan sesorang, yang hingga saat ini masih berinteraksi secara sosial. Temanjenis ini lazimnya berada pada satu desa yang sama dengan kandidat. Kedekatan jarak atau lingkungan sosial, menyebabkan di antara mereka masih sering dipertemukan di forum-forum sosial formal maupun non-formal. Forum jagongan seringkali menjadi forum sosial yang mempertemukan mereka.

Teman lama merujuk pada pertemanan antara kandidat dan seseorang yang bersumber 
dari berbagai kegiatan di masa lalu, dan tidak lagi memiliki interaksi sosial yang siginifikan. Sebagai contoh, seorang kandidat yang berdomisili di desa Mranggen, pernah menempuh pendidikan di sekolah yang muridmuridnya berasal dari desa-desa di Kecamatan Mranggen, bahkan dari desa-desa di sekitar Kecamatan Mranggen. Teman-teman tersebut sejatinya sudah tidak aktif berinteraksi secara sosial dengan kandidat dalam keseharian, karena jarak geografis dan perbedaan lingkungan pekerjaan yang tidak memungkinkan untuk terjadinya interkasi sosial secara rutin. Ketika kandidat ingin memanfaatkan teman-teman sekolah tersebut sebagai tim sukses mandiri, kandidat membuka kontak dan melakukan interaksi.

Selain keluarga besar dan teman, kandidat juga memanfaatkan orang-orang yang berada pada satu organisasi dengannya, atau disebut memiliki afiliasi organisasi yang sama. Cakupan orang-orang ini dapat lebih luas dari teman. Sebagai contoh, seorang kandidat adalah pengurus salah satu organisasi di tingkat Kabupaten. Kandidat tersebut memanfaatkan orang-orang yang ada pada struktur organisasi tersebut di tingkat desa. Karena organisasi tersebut memiliki tingkat kepengurusan yang lengkap di seluruh desa, maka pemanfaatan orang-orang dengan afiliasi organisasi yang sama, dapat mengisi kekosongan wilayah yang tidak dapat dijangkau melalui keluarga besar ataupun teman.

Organisasi yang pada umumnya dimanfaatkan oleh kandidat di lokasi penelitian adalah organisasi keagamaan dan organisasi kepemudaan. Nahdlatul Ulama sebagai organisasi keagamaan terbesar dan memiliki struktur aktif hingga tingkat desa, menjadi magnet yang diperebutkan oleh banyak kandidat. Pada beberapakasus,partaipolitikmempertimbangkan latar belakang organisasi yang dimiliki bakal kandidat. Sebagai contoh, seseorang diajukan oleh partai politik untuk menjadi kandidat karena posisinya sebagai elit di kepengurusan Nahdlatul Ulama. Begitupun sebaliknya, organisasi-organisasi yang merasa memiliki basis masa yang kuat dan besar, berusaha menempatkan kaderkadernya untuk menduduki jabatan-jabatan politik. Secara kelembagaan, afiliasi organisasi ini mempermudah kandidat untuk menemukan orang-orang yang akan menjadi aktor simpul di tim sukses.
Beberapa kandidat juga memanfaatkan saluran lain, yakni mitra kerja dan guru. Pada sedikit kasus, kandidat memiliki bisnis atau usaha yang melibatkan orang-orang dari berbagai desa, tergantung besaran usaha nya. Sebagai contoh, seorang kandidat memiliki usaha penangkapan ikan yang melibatkan puluhan pekerja kapal. Kandidat tersebut memanfaatkan pekerjanya untuk menjadi aktor simpul di desa masingmasing yang masih dalam lingkup daerah pemilihan kandidat tersebut. Bukan hanya memanfaatkan pekerja, kandidat juga dapat memanfaatkan mitra kerja yang sejajar, seperti yang dilakukan salah seorang kandidat yang berprofesi sebagai pengembang perumahan, dengan memanfaatkan kontraktor-kontraktor pembangunan rumah sebagai aktor simpul di desa masing-masing.

Pemanfaatan guru oleh kandidat, lebih banyak dijumpai dalam bentuk pemanfaatan guru agama. Di beberapa pedesaan di Kabupaten Demak, guru agama atau lazim disebut Kyai memiliki pengaruh di masyarakat. Kandidat memanfaatkannya sebagai jaminan atas kelayakan sang murid menjadi wakil rakyat. Prosedur yang biasa dilalui oleh kandidat adalah, sebagai murid meminta restu kepada kyai. Ketika kyai memberikan restu, ini menjadi pintu masuk untuk meminta dukungan kyai. Kandidat akan memohon kepada kyai untuk mengkampanyekan kandidat tersebut.

Hubungan-hubungan sebagaimana di atas, dapat menjelaskan posisi awal pembentukan tim sukses mandiri, bukan hanya pada kandidat baru, namun juga kandidat petahanan. Perbedaan antara kandidat baru dan kandidat petahanan adalah hanya pada kapan pembentukan tim sukses dilakukan. Pada kandidat baru, pelembagaan dilakukan pada periode pemilu DPRD Kabupaten 2019, sedangkan pada kandidat petahanan dapat terjadi pada periode pemilu sebelumnya.

Namun tidak sedikit dijumpai, kandidat petahanan juga membentuk tim sukses mandiri baru yang berbeda dengan tim yang membantunya di pemilu sebelumnya. Beberapa kandidat mengungkapkan sulitnya mempertahankan tim sukses yang membantunya di pemilu sebelumnya, karena tuntutan atas kepentingan-kepentingan aktor tim sukses, khususnya yang memiliki orientasi transaksional dengan kandidat. Ketika aktor-aktor tersebut 
kecewa terhadap kandidat, maka kandidat tidak dapat memanfaatkan aktor-aktor tersebut di pemilu berikutnya.

Selain memanfaatkan saluran sosial yang dimiliki kandidat untuk menjadi aktor simpul tim sukses, kandidat juga memanfaatkan orangorang yang baru dikenalnya. Seorang kandidat memberikan kesaksian atas dilema yang harus dihadapinya ketika tidak memiliki anggota keluarga atau teman atau jaringan sosial apapun di suatu desa, sementara kandidat tersebut harus mendapatkan suara di desa tersebut. Dengan memanfaatkan perantara, kandidat diperkenalkan kepada orang-orang baru tersebut. Dalam waktu singkat, kandidat perlu membangun ikatan emosional antara dirinya dengan orang baru. Beberapa kasus menunjukkan keberhasilan pembentukan ikatan emosional tersebut. Namun pada banyak kasus lainnya, kandidat gagal membangun ikatan emosional, dan kinerja tim sukses didasarkan murni transaksional.

Mayoritas kandidat yang diwawancarai menyatakan bahwa mereka mengambil sikap berhati-hati pada tim sukses yang memiliki aktor simpul orang baru. Bahkan para kandidat terkesan setengah hati dalam menggerakkan dan menyediakan sumber daya pada tim sukses tersebut. Beberapa kandidat menjelaskan tingkat spekulasi yang harus dihadapinya dengan orang baru. Pertama, komitmen orang baru belum tentu ada pada kadaryang layak. Kedua, ketidakjelasan jangkauan sosial yang dimiliki orang baru, baik dalam menjangkau pemilih maupun membentuk tingkatan tim sukses di bawahnya.

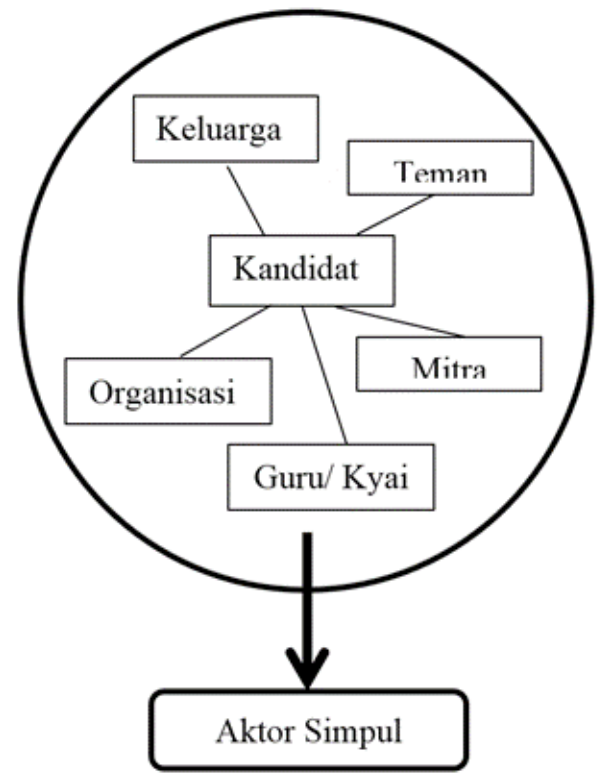

Gambar 4. Pembentukan Tim Sukses
Dua hal tersebut berimbas pada tingkat kerawanan terhadap penyimpangan. Penyimpangan terberat adalah penguasaan uang atau barang dari kandidat, yang seharusnya disampaikan ke pemilih. Penyimpangan paling ringan adalah tingkat keseriusan yang rendah dalam bekerja, sehingga standar kerja yang diharapkan oleh kandidat tidak dapat tercapai secara penuh. Karena tingkat spekulasi yang tinggi, seorang kandidat menyatakan secara tegas, tidak bersedia memakai orang yang baru dikenalnya sebagai aktor simpul tim sukses mandiri, dan memilih untuk melepaskan desa dimana kandidat tidak memiliki saluran sosial.

Dari pemaparan di atas dapat diketahui adanya dua latar belakang keterhubungan kandidat dan aktor simpul, yakni keterhubungan langsung dan keterhubungan tidak langsung. Keterhubungan langsung merujuk pada keadaan kandidat dan aktor simpul yang telah memiliki interaksi sosial, jauh sebelum periode kepemiluan. Interkasi sosial tersebut di luar kepentingan pemenangan kandidat. Keterhubungan langsung mencakup hubungan kekeluargaan, pertemanan, afiliasi organisasi, guru-murid, ataupun mitra kerja (lihat bagan 4). Keterhubungan tidak langsung merujuk pada keadaan kandidat dan aktor simpul yang sebelumnya tidak memiliki interaksi sosial dalam jenis apapun. Keterhubungan tidak langsung ditandai dengan adanya aktor perantara yang memperkenalkan kandidat dengan aktor simpul tersebut. Dengan kata lain, perkenalan mereka murni didasari untuk kepentingan pemenangan kandidat.

\section{Penggunaan Jejaring Sosial}

Berbagai literatur yang mengkaji tim sukses mandiri, seperti Aspinall (2014), Zarazaga, 2014),dan Finan dan Schechter (2012 menjelaskan bagaimana komponen lembaga tersebut adalah berupa jejaring sosial. Fakta lapangan menunjukkan bahwa tim sukses mandiri bukan hanya memiliki komponen berupa jejaring sosial, namun juga dilahirkan oleh jejaring sosial kandidat dan aktor simpul.

Pembentukan tim sukses mandiri yang bertumpu pada kandidat dan aktor simpul, terjadi melalui salah satu proses berikut. Pertama, penciptaan jejaring baru, yakni pembentukan tim sukses mandiri dengan melibatkan orangorang baru yang sebelumnya tidak memiliki 
hubungan sosial dengan kandidat sebagai aktor simpul. Kedua, penggunaan jejaring sosial asli, yakni pembentukan tim sukses mandiri dengan memanfaatkan lingkungan atau sumber daya sosial yang telah dimiliki oleh kandidat sebagai sumber pengisian aktor-aktor simpul. Sumber daya sosial dominan yang dimanfaatkan oleh calon anggota legislatif 2019 meliputi keluarga, teman, organisasi, ataupunpekerjaan. Dengan segala pertimbangan spekulasi dan potensi, kandidat cenderung memprioritaskan pengalihan fungsi sosial, dan sedapat mungkin tidak menggunakan penciptaan fungsi baru.

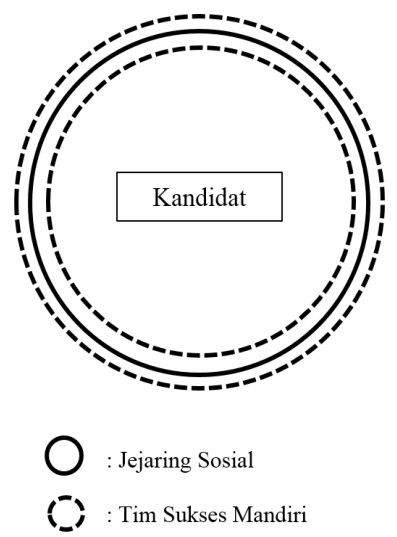

Bagan 5. Jangkauan Pembentukan Tim ukses Mandiri

Fakta-faktatersebutmenunjukkanbahwatim sukses mandiri bukan hanya dapat mengalami tekanan sosial (Tawakkal dkk, 2017), namun juga dalam proses pembentukan tim sukses mandirioleh kandidat tidak dapat terlepas dari jejaring sosial yang dimiliki oleh kandidat (lihat bagan 5). Meskipuin dapat lebih sempit ataupun lebih luas dari lingkungan sosialnya, namun tetap berjalan di sekitar batas lingkungan sosialnya. Lebih sempit dari lingkungan sosial merujuk pada keadaan kandidat yang tidak memanfaatkan sumber daya sosial tertentu di lingkungannya untuk membangun tim sukses mandiri. Situasi ini dapat disebabkan oleh kekurangan sumber daya finansial, ataupun kecilnya potensi suara bila memanfaatkan sumber daya sosial tersebut. Lebih luas dari lingkungan sosialnya merujuk pada keadaan kandidat yang memanfaatkan orang-orang baru di luar lingkungan sosialnya untuk membangun tim sukses mandiri. Meskipun di luar lingkungan sosialnya, namun tidak jauh dari batas maksimal lingkungannya. Pada kasus ini, hanya melibatkan satu jenjang perantara dari lingkungan sosialnya untuk memperkenalkan dengan orang baru.

\section{SIMPULAN}

Tim sukses mandiri di Pemilu legislatif 2019, yakni tim pemenangan yang berisi orangorang non-partai, terdiri dari beberapa orang yang terorganisasi dalam unit-unit kecil di tingkat desa. Unit-unit tersebut berfungsi mempengaruhi pemilih untuk memberikan suaranya pada kandidat tertentu, dengan mendistribusikan materi-materi kampanye yang bersifat materi maupunnon-materi. Masing-masingunittersebut terdiri dari beberapa orang yang terorganisasikan secara hirarkhis hingga tingkat pemilih, meliputi tim sukses Desa, tim sukses RW, dan tim sukses RT, dengan satu aktor simpul yang terhubung dan berinteraksi langsung dengan kandidat. Aktor simpul inilah yang bertanggungjawab dalam menggerakkan tim sukses mandiri dalam pemenangan kandidat.

Mengingat keterbatasan kandidat dalam menjangkau setiap individu dalam satu unit tim sukses mandiri, maka aktor simpul menjadi aktor kunci dalam menggerakkan unit-unit tim sukses. Sikap dan perilaku aktor-aktor simpul akan berpengaruh besar terhadap kinerja unitunitnya. Sehingga dapat dikatakan bahwa pertaruhan terbesar kandidat dalam pemanfaatan tim sukses mandiri, adalah pada pemilihan aktor-aktor simpul di setiap unit.

Pada situasi ini, pembentukan tim sukses terjadi dengan menciptakan jejaring baru, yakni pembentukan tim sukses mandiri dengan melibatkan orang-orang baru yang sebelumnya tidak memiliki hubungan sosial dengan kandidat sebagai aktor simpul, dan atau dengan menggunakan jejaring sosial asli, yakni pembentukan tim sukses mandiri dengan memanfaatkan lingkungan atau sumber daya sosial yang telah dimiliki oleh kandidat sebagai sumber pengisian aktor-aktor simpul. Penggunaan jejaring sosial asli yang dimiliki kandidat, adalah pola yang lebih dipilih oleh kandidat.

Gambaran besar yang dapat diambil adalah, proses pembentukan tim sukses mandirioleh kandidat hanya bergerak di seputarjejaring sosial yang dimiliki oleh kandidat, ataupun dengan pergeseran yang masih berhimpitandengan jejaring sosial asli. Pembentukan tim sukses yang bergerak di seputar lingkungan sosial kandidat, menunjukkan bahwatim sukses mandiri lebih dari sekedar tim marketing yang direkrut melalui pembukaan lowongan pekerjaan. 
Namun, dengan keterbatasan lokasi dan karakter masyarakat yang menjadi obyek penelitian, artikel ini masih menyisakan pertanyaan besar terkait pembentukan tim sukses mandiri. Karakteristik masyarakat desa yang memiliki interaksi sosial tinggi antara individu, tentu berbeda dengan masyarakat perkotaan.

Pembentukan tim sukses kandidat yang memiliki daerah pemilih di perkotaan, bisa jadi melalui proses yang berbeda. Apakah ikatan sosial yang lemah di masyarakat perkotaan mendorong kandidat untuk mengoptimalkan pola pembentukan fungsi baru? Seandainya kandidat di perkotaan memiliki teman, apakah memiliki kadar keterlibatan yang sama dengan kandidat di pedesaan? Secara umum, apakah kandidat memiliki kendala dalam melakukan pengalihan fungsi sosial? Mengingat kemungkinan adanya dua atau lebih kandidat yang berasal dari lingkungan sosial yang sama, tentu menarik untuk mengetahui tantangan yang dihadapi kandidat dalam pembentukan tim sukses mandiri. Terbuka bagi kami dan peneliti lain untuk memperluas dan mengkaji lebih jauh pertanyaanpertanyaan yang belum mampu terjawab di artikel ini.

\section{DAFTAR PUSTAKA}

Aspinall, E., Rohman, N., Hamdi, A. Z., Rubaidi, \& Triantini, Z. E. (2017). Vote Buying in Indonesia: Candidate Strategies, Market Logic and Effectiveness. Journal of East Asian Studies, 17(01), 1-27

Aspinall, E, \& Sukmajati, M. (2015). Patronase dan Klientelisme dalam Politik Elektoral di Indonesia. Dalam Edward Aspinall \&MadaSukmajati (ed.). Politik Uang di Indonesia, Patronase dan Klientelisme pada Pemilu Legislatif 2014. Yogyakarta: Polgov.

Aspinall, E. (2014). When Brokers Betray: Clientelism, Social Networks, and Electoral Politics in Indonesia. Critical Asian Studies, 46, (4), 545-570.

Baldwin, K. (2016). The Paradox of Traditional Chiefs in Democratic Africa. New York: Cambridge University Press.

Blaydes, L. (2006). Who Votes in Authoritarian Elections and Why? Determinants of Voter Turnout in Contemporary Egypt.The 2006
Annual Meeting of the American Political Science Association. Philadelphia, PA.

Callahan, W.A. (2018). Pollwatching, Elections and Civil Society in Southeast Asia. New York: Routledge.

Finan, F. \& Schechter, L. (2012). Vote-Buying And Reciprocity. Econometrica, 80, (2), 863-881.

Frye, T., Reuter, O., \& Szakonyi, D. (2019). Vote Brokers, Clientelist Appeals, and Voter Turnout: Evidence from Russia and Venezuela. World Politics, 71, (4), 710746.

Frye, T., Reuter, O., \& Szakonyi, D. (2019). Hitting Them With Carrots: Voter Intimidation and Vote Buying in Russia. British Journal of Political Science, 49, (3), 857-881.

Geertz, C. (1989). Abangan, Santri, Priyayi dalam Masyarakat Jawa, alih bahasa Aswab Mahasin. Jakarta: Pustaka Jaya

Gingerich, D.W., \& Medina, L.F. (2013). The Endurance and Eclipse of The Controlled Vote: AFormal Model of Vote Brokerage Under The SecretBallot. Economics \& Politics, 25, (3), 453-480.

Hellmann, O. (2014). Electoral Reform in Asia: Institutional Engineering against 'Money Politics. Japanese Journal of Political Science, 15, (2), 275-298.

Kamus lengkap, https://kamuslengkap.com/ kamus/politik/arti-kata/team-sukses

Kennedy, J.J. (2010). The Price of Democracy: Vote Buying and Village Elections in China. Asian Politics \& Policy, 2, (4), 617-631.

Larreguy,H., Marshall,J., \& Querub'In,P.(2016). Parties, Brokers, And Voter Mobilization: How Turnout Buying Depends Upon The Party's Capacity To Monitor Brokers. American Political Science Review, 110, (1), 160-179.

Mattlin, M. (2004).Nested Pyramid Structures: Political Parties in Taiwanese Elections. The China Quarterly, 180, 10311049.

McCarty, C., Bernard, H.R., Killworth, P.D., Shelley, G.A. \& Johnson, E.C. (1997). 
Eliciting Representative Samples of Personal Networks. Social Networks, 19, 303-323.

Miles, M.B., Huberman, M.A. (1984). Qualitative Data Analysis: A Sourcebook of New Methode. London: Sage Publications.

Nurcholis, H. (2011). Dua Ratus Tahun Demokrasi Desa: Potret Kegagalan Adopsi Nilai Demokrasi Oleh Bangsa Indonesia. Proceeding Semnas FISIP-UT 2011. Jakarta.

Ocantos, E.G. (2012). Vote Buying and Social Desirability Bias:Experimental Evidence from Nicaragua. American Journal of Political Science, 56, (1), 202-217.

Rahman, N. (2015). Pati, Jawa Tengah: Target, Teknik dan Makna dari Pembelian Suara. DalamEdwardAspinall \&MadaSukmajati (ed.). Politik Uang di Indonesia, Patronase dan Klientelisme pada Pemilu Legislatif 2014. Yogyakarta: Polgov.

Rueda, M.R. (2017). Small Aggregates, Big Manipulation: Vote Buying Enforcement and Collective Monitoring. American Journal of Political Science, 61, (1), 163177.

Scott, J.C. (1972). Patron-Client Politics And Political Change in Southeast Asia. The American Political Science Review, 66, (1), 91-113.
Tawakkal, G.T.I. (2017). Gapit Sebagai Potensi Demokrasi: Bekerjanya Jejaring Dalam Pilkada Demak 2015. Disertasi S3 Ilmu Sosial Universitas Diponegoro Semarang.

Tawakkal, G.T.I. (2017). Gapit: Jaringan Mobilisasi Suara di Pilkades. Jurnal Ilmu Politik, 2, (1), 31-46.

Tawakkal, G.T.I., Kistanto, N.H., Asy'ari, H., Pradhanawati, A. \& Garner, A.D. (2017). Why Brokers Don't Betray: Social Status and Brokerage Activity in Central Java. Asian Affairs: An American Review, 44, (2), 52-68.

Tawakkal, G.T.I. (2009). Peran Partai Politik Dalam Mobilisasi Pemilih Studi Kegagalan Parpol Pada Pemilu Legislatif Di Kabupaten Demak 2009. Tesis S2 Ilmu Politik Universitas Diponegoro, Semarang.

Triantini, Z.E.(2015). Blora, Jawa Tengah: Sabet Sebagai Penentu Kemenangan. Dalam Edward Aspinall \&MadaSukmajati (ed.). Politik Uang di Indonesia, Patronase dan Klientelisme pada Pemilu Legislatif 2014. Yogyakarta: Polgov.

Wu, C., \& Huang, C. (2004). Politics and Judiciary Verdicts on Vote-Buying Litigation in Taiwan. Asian Survey,44, (5), 755-770.

Zarazaga, R. (2014). Vote Buying and Asymetric Information. Working Paper \#398. Notre Dame: The Kellogg Institute for International Studies. 